\title{
The Influence of Demographics and Religiosity Factors on Islamic Financial Literacy
}

\author{
Djubaedi Yunus, Ahmad Rodoni, Amilin, Riris Aishah Prasetyowati \\ UIN Syarif Hidayatullah, Jakarta, Indonesia \\ djubaedi.yunus@uinjkt.ac.id,ahmad.rodoni@uinjkt.ac.id,amilin@uinjkt.ac.id \\ riris.aishah@uinjkt.ac.id
}

\begin{abstract}
The purpose of this study is to examine the influence of demographics and religiosity on Islamic financial literacy. Using a quantitative approach with a Likert scale questionnaire-based survey method, the population was 2800 respondents of Sharia Bank customers in Jakarta, Bogor, Depok, Bekasi, Tangerang, Surabaya, Semarang, and other cities in Indonesia. The accidental method was used and obtained a selected sample size of 400 respondents, which were analyzed using the Partial Least Square (PLS) method. The novelty shows that dimensions that do not support the significant effect of demographic and religiosity variables on Islamic financial literacy are income, moral, and experience if associated with moral hazard because they are supported by manifestations related to morality. The results of hypothesis testing show that there is a significant effect of demographics on religiosity, a significant effect of demography on Islamic financial literacy, and a significant effect of religiosity on Islamic financial literacy.
\end{abstract}

Keywords: demographics, religiosity, Islamic financial literacy, Partial Least Square (PLS)

Permalink/DOI: https://doi.org/10.18326/infs13.v15i1.91-116 


\section{Introduction}

Regarding the influence of demography and religiosity on financial literacy, there are differences in views on the concept of monotheism and morals according to per capita income. Countries with higher per capita income, such as the United States, Netherlands, Germany, Australia, are less likely to believe in God, but likely to violate morals (Pew Research Center, 2020:4). About the relationship between wealth and the importance of religion, the higher the purchasing power of the population of a country, the lower the importance of religion; and the lower the purchasing power of the population of a country, the higher the role of religion in social life in European countries (Pew Research,2018:18). The concept of religiosity in the field of economics and Islamic finance helps to improve the welfare of the community thereby accelerating national economic growth (Soma, et.all:2017:25). Religiosity and self-adjustment affect employee performance improvement (N.Ermawati,2018:106). Students' financial literacy index is influenced by demographic factors, gender, age, marital status, employment, education, and income. On the other hand, parental education does not affect financial literacy (MM \& SK Meimouneh,2014:64), factors that influence consumers to buy halal products and choose Islamic credit cards by using knowledge and religiosity. Knowledge and religiosity influence the acceptance of halal products and Islamic credit cards (Johan and Putit,2016:480).

A person's ability to use financial knowledge, abilities, and attitudes to manage their financial resources by following Islamic teachings such as to opt zakat institution includes spending rational consumption, saving in an account, and averse risk. Definition of Islamic financial literacy including the influence to other sharia aspects such as allocating funds for zakat, donations, sodaqo, and waqf (A.Sardiana,2018:17). Muzaki's gender and education level positively affects choosing certain zakat institution, either mosque or Bazarnas (State/National Zakat Institution) or directly to zakat recipient personally. Conversely, muzaki's religiosity is not significantly affecting the trend in the choice of zakat recipients (AM. Muthohar,2015:25). Most Muslims who have a high enough level of religiosity significantly influences consumption rationality 
(Anton Bawono,2014:306). To fulfill the physical and spiritual does not depend on the income level. Increasing income level is not more spending for physical consumption but more spending for spiritual consumption (other than property zakat) such as infaq or sodako or waqf (Syaparuddin,2019:1). Islamic business ethics connect to one of religiosity indicators namely consequence or moral (shiddiq, istiqomah dan tabligh) in the business world, that has a significant effect on asymmetric communication. To develop a risk reduction model of mudharabah financing is by escalating financing performance (the competence variables account Syariah officer, business ethics, and information asymmetry) in Islamic Microfinance Institutions in Jember and Bondowoso (SM.Wardayati, et all,2014:331). the development of human resources who know compliance sharia in Islamic Banking School Yogyakarta is designed with four main competencies, core competencies, behavior, functional and managerial competence (Syaparuddin,2014:351).

Based on the description of the background of the problem above, the problem formulation as the main target to be achieved by this study are:1) to measure the significant effect of demographic exogenous latency on endogenous latent religiosity, 2) to measure the significant effect of demographic exogenous latency on endogenous latency of Islamic financial literacy, 3) to measure the significant influence of religiosity on Islamic financial literacy. The purpose of this study was to explore the significant influence of demographic and religiosity variables on Islamic financial literacy and the significant influence of demographics on religiosity and to examine the effectiveness of the influence of intervening variables in mediating the relationship between exogenous demographic variables and endogenous variables of Islamic financial literacy in Islamic communities in Jakarta, Bogor, Depok, Tanggerang, Bekasi, and several other big cities in Indonesia.

Demographics is represented as humans or people who have characteristics. Religiosity is behaving under the guidance of religion. Religiosity and religion cannot be separated from one another because religion is the main source of religiosity. The religion referred to here is Islam, and the main sources of Islamic teachings are the Qur'an and Hadith. People who have religiosity are people who 
behave religiously or behave following Islamic teachings of which sources of teachings are Al-Qur'an and Hadith. Islamic financial literacy is conventional finance plus aspects of sharia. Conventional economics is harmonized with the Qur'an and Sunnab and the opinions of scholars (inductive method). The financial theory is derived from the Qur'an and Sunnab so that the terms financial and financial literacy can mean Islamic financial literacy and Islamic finance, but they cannot be interpreted as conventional financial literacy and conventional finance (deductive theory). Therefore, the influence of demography and religiosity on Islamic financial literacy is that Muslims become understand Islamic finance.

Demographics or population or a description of the population (EFL. Amaral, 2019:11), has characteristics such as age, education, gender, and so on (Wunsch, 2007:97). Demographics is represented as humans or people who have characteristics. The value varies (fluctuates) from case to case, and can be empirically calculated (EFL. Amaral, 2019:21) because it has the potential associated with behavior and attitudes that can build stratification ( Koch,2016:23), and is an important element in the economic development of a region (Ekonomi Kependudukan, Universitas Pajajaran) The characteristics of the research chosen in this study will emphasize characteristics that are "certain" when research, for example, gender must only be two choices of men or women, or the exact age is young or adult, or certain education is not higher education and higher education, religion, place of residence, account. bank, education, status, and employment.

Religiosity can be used as a variable in research, including in Islamic finance research. Religiosity and religion cannot be separated from one another because religion is the main source of religiosity. The religion referred to here is Islam, and the main sources of Islamic teachings are Al-Qur'an and Hadith. People who have religiosity are those who behave religiosity or behave following Islamic teachings of which source of teachings are Al-Qur'an and Hadith. The research instrument used refers to Glock (A. and S.Rehman,2010:63), which consists of five dimensions of religiosity variables, namely monotheism, rituals, intellectuals, consequences, and experiences. Tawhid is related to overall beliefs related to religion such as the 
belief in the existence of Allah SWT, the Prophet, Al-Qur'an and Hadith. Ritual indicators include statements about practices that are pillars of religion such as prayer, fasting, reading Al-Qur'an, giving zakat, and donating alms. Intellectual indicators (muamalah) include statements about religious knowledge; how to earn a living; avoid sins, both major and minor sins; and carry out all religious orders in daily life. The consequence indicator (morals) relies on the importance of religion itself by conveying a statement about respecting other people, recognizing the rights of others according to Islam, being honest, being fair, and avoiding dishonorable acts. Experiential indicators include religious practice by mentioning statements that practice deviating from belief, demonic abuse, fear of Allah SWT, remembering Allah's punishment if they deviate from Islamic teachings.

Until now, Islamic financial literacy does not have a definition that can be used as a working reference; even though there is an agreement among sharia experts that what is meant by Islamic financial literacy is financial literacy (conventional) which includes components according to the requirements of sharia (ALHA \& Razak, 2018:63). The concept of Islamic financial literacy generally uses the concept of conventional financial literacy coupled with aspects of sharia. Since there is no standard concept of Islamic financial literacy, academics and researchers must define Islamic financial literacy (ALHA \& Razak , 2018:64). The discussion of sharia on Islamic financial literacy contained in the sharia economic literature still uses the inductive method, which the existing conventional economic theory that is then adjusted to the Qur'an and Sunnah or some of the opinions of scholars. The discussion uses the deductive method, namely he existing conventional financial theory, which departs from the sources of the Qur'an and the Sunnah (A.W \& A Al-Faizin,2018:9). Six dimensions of endogenous variables of financial literacy consist of product and service characteristics manifest, community numeracy manifest, public attitude and behavior manifest, delivery channel manifest (means used) per sector, information source manifest, and consultant party manifest.

The following is previous relevant research that describes the results of research conducted by previous researchers that are 
relevant to this research. The Financial Services Authority (OJK) in the 2016 National Research on Indonesian Financial Literacy and Inclusion, uses demographic as an independent variable with indicators of gender, age, education, income expenditure, occupation, and geographic distribution. The results showed that the Islamic financial literacy index in 2016 was 8.11\%, spread across the sharia banking sector at $6.63 \%$, sharia insurance at $2.51 \%$, sharia pawnshops at $1.63 \%$, sharia financing institutions at $0.19 \%$, and other sharia sectors at less than 1.0\% (OJK, 2019:1). In 2013, gender, age, education, income, occupation, and geographic distribution were used. One of the problem formulations is the impact of financial literacy on sharia financial service preferences, which aims to examine whether financial literacy and indicators of knowledge, expertise, and belief significantly influence the preference for using Islamic financial services simultaneously. The financial literacy index (sharia and conventional) was $21.84 \%$, spread across banking at $21.8 \%$, insurance at $17.84 \%$, financing institutions at $9.80 \%$, pension funds at $7.13 \%$, the capital market at $3.79 \%$, and fiduciary services at $14.85 \%$ (OJK, 2019:1)

Saeed Meimouneh, et al (2014), revealed that research on a population of 150 university students in Iran, showed that the student financial literacy index is influenced by gender demographic factors, age, marital status, occupation, education, and income. On the other hand, parental education does not financial literacy. Johan and Putit (2016:480) on their research found that factors that influence consumers to buy halal products and choose Islamic credit cards were knowledge and religiosity. Knowledge and religiosity influence the acceptance of halal products and Islamic credit cards.

Atkinson and Messy (2012:23) focused on measuring financial knowledge, behavior, and attitudes based on socio-demographics. The results indicated a lack of financial knowledge but there was room for improvement in financial behavior, while attitudes towards finance vary. The other results of this study serve as a reference to identify needs and gaps in the field of financial education and develop development strategies.

The results of research by Sangita A/P Jeyaram and Mazlina 
Binti Mustapha (2015:1) showed that students who are registered as students majoring in accounting and business have a higher level of financial literacy than students of other majors, the male student literacy index is higher than female students, and the Chinese student literacy index is significantly higher than other ethnic students.

Nanik Ermawati (2018) concluded that taxpayer compliance is influenced by religiosity, and taxpayer awareness, and it is not influenced by tax knowledge. Amir Ali Shusha's research (2017:67) showed that the demographic characteristics of gender, age, education level, and income that can meet their needs have a significant influence on financial risk tolerance, and financial literacy influence the relationship between individual demographic characteristics and their tendency to take the risk.

Rita Kusumadewi, et al. (2016:111), in Islamic Financial Literacy in Islamic Boarding Schools, states that the use of conventional bank accounts is more than Islamic banks and Rural Banks (BPR)/ Sharia Rural Banks (BPRS) respectively at 63\%, 36\%, and 1\% by students in the pesantren (Islamic Boarding School) who are better understand sharia finance in terms of its financial management than the general public. This means that the students are still dominated by conventional bank thinking.

The gaps contained in this study from previous relevant research are 1) demographic dimensions, namely differences in income levels; 2) the dimension of religiosity that lies in the level of measuring morals and experience, and; 3) the dimension of Islamic financial literacy that lies in the level of measuring attitudes and behaviors related to religiosity, and differences in information sources related to demographic. The novelty of this research in the dimensions that do not support demographic and religiosity variables on Islamic financial literacy, namely the level of income, morals, and experience when associated with moral hazard because they are supported by manifestations related to morals . This finding is supported by the results of a PEW study conducted in 2019, which stated that in Western Europe, people believe in God but do not need to be moral. 


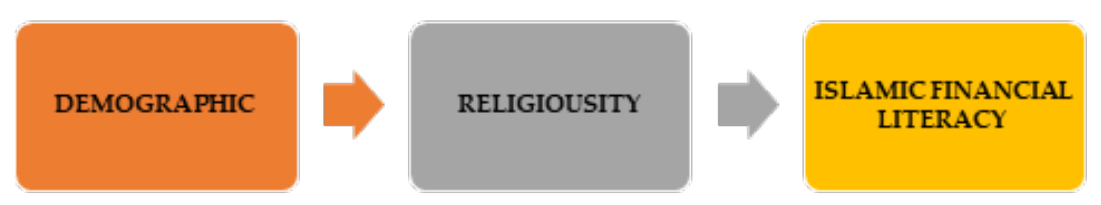

Figure 1. Conceptual Maps of Islamic Financial Literacy Source: Authors documentation

The variable in this study is an exogenous latent variable consisting of the demographic of the respondent, and religiosity serves as a mediating variable, because, on one hand, it is an endogenous variable for demographic variables and, on the other hand, as an exogenous variable for endogenous Islamic finance literacy variable (figure 1). Demographic characteristics of respondents who function as exogenous variables in this study consist of gender, age, education level, and income level, and for research purpose is processed through statistical tests that have different units. Description of the mediating variable (intervening) religiosity consists of the 12 statements that relate to the religiosity variable that is distributed into the five variables, namely tawhid manifest, the ritualistic manifest, the intellectual manifest (muamalah), the consequence manifest (morals), and the experience manifest. The description of the endogenous variable literation of Islamic finance consists of 46 statement items relating to the Islamic financial literacy variable that is distributed into six manifest variables, namely, knowledge of product and service characteristics, manifest of public numeracy skills, manifest of attitudes and behavior, manifest of delivery channels per sector, manifest of information sources, and consulted party for financial advice.

\section{Methods}

A person's ability to use financial knowledge, abilities, and attitudes to manage their financial resources by following Islamic teachings such as to opt zakat institution includes spending rational consumption, saving in an account, and averse risk. The research method started by determining the type and design of the research used, which includes the researchers' consideration in choosing a quantitative approach for empirical testing of its latent variables. The next step was defining the operationalization of the research variables to 
obtain data that can be measured and assessed. Furthermore, data analysis was carried out based on the tabulation of data collected from survey results and direct exploration of respondents. The data collection procedure was carried out by using deductive analysis techniques that that aim to test hypotheses based on previous theory and research to answer research questions.

The choice of the PLS method is based on the consideration that in this study there were three latent variables formed from formative and reflective indicators in this study. The formative model assumes that the latent construct or variable affects the indicator or manifest where the causal relationship is from latent to the indicator or manifest. Therefore, changes that occur in the manifest will appear in the latent variable changes. Meanwhile the reflective relationship model that assumes/describes each indicator or manifest is a measurement of error that aims at latent variables according to Sarwono and Nurimawati (2016:13). This quantitative data analysis method is the statistical technique of Structural Equation Model - Partial Least Square (SEM-PLS) with its various variations, which are simplified into a path analysis model to examine factors that affect the level of Islamic financial literacy directly or indirectly through religious behaviour.

\section{Data Sources}

The primary source of this research is the answers to a questionnaire sent to the Muslim and non-Muslim communities in several cities in Indonesia, with as many as 2800 respondents. Questionnaires were sent to respondents twice. The questionnaire was distributed through social media in the WhatsApp (online) application , Instagram, Twitter, Facebook, E-mail, and other social media. The questionnaire was made using the google form application, containing statements submitted in writing made by researchers, and then respondents filled out or answered questionnaires made by giving a checkmark (checklist). There were 400 of the total 2,800 respondents who received a questionnaire, sent it back.

Secondary data of this research comes from the literature review, including books, articles, journals, in both hard copy and soft copy or online, and other literature reviews related to the 
results of previous relevant research and other sources that are related to this research.

\section{Model Development}

The results of this research hypothesis test are to obtain a probability that the inner model consists of three probabilities and the outer model consists of 15 probabilities. Inner Model: Demographic factors have a significant direct effect on religiosity; Demographic factors have a significant direct effect on Islamic financial literacy; The religiosity factor has a significant direct effect on Islamic financial literacy. Outer Model: Gender factors affect demographics; Age factor affecting demographics; Education level factor affects demographics; Income factor affects demographics; Monotheism factor affects religiosity; Ritual factors influence religiosity; Intellectual factors influence religiosity; Consequence factors affect religiosity; Experience factor influences religiosity; Product and service knowledge factors affect Islamic financial literacy; The numeracy factor influences Islamic financial literacy; Attitude and behavior factors affect Islamic financial literacy; Delivery channel factors affect Islamic financial literacy; Sources of information affect Islamic financial literacy; Reference factors affect Islamic financial literacy.

\section{Data Analysis}

The latent variables in this study consist of demographic variables, religiosity, and Islamic financial literacy, while the indicator variables for latent variables can be defined as manifest variables or observable variables as follows.

\section{Latent Demographics (X1)}

X1.1 - Gender Manifest. Gender has a nominal scale for women and men, which can be stated in the classification with the notation 0 (zero) for women and 1 (one) gender groups. X1.2 - Age Manifest. Age is classified into the young age group with notation 0 (zero) for ages up to 35 years and adult notation 1 (one) for ages above 36 years. X1.3 - Educational Strata Manifest. It is classified as Primary and Secondary Education (PDM) with a classification notation of 0 (zero) and the S-1, S-2 and S-3 education strata are stated as higher education classifications with a notation of 1 (one). X1.4 - Earnings level manifest. It is classified based on a reference to the average 
or average income of the respondent, provided that respondents who have an income below the average value are classified as low income with a notation of 0 (zero), namely income less than or equal to five million rupiahs per month, and respondents who have high income is classified as high income with a notation of 1 (one), where the income is above five million rupiahs per month.

\section{Latent Religiosity (X2)}

X2.1 - Tawhid Manifest. Tawhid (ideological) is the dogmatic scale of a person in religion, for example, believing in God, angels, heaven, apocalypse, and so on. X2.2 - Ritual Manifest. Ritual is the activity of worshiping to comply with the norms and religious rules of his choosing; X2.3 - Intellectual Manifest. Intellectual (Muamalab), is a religious concept that is implemented in social life, for example working, saving money in Islamic banks; X2.5 - Experience Manifest. Experience is felt by almost all people, regardless of religion.

\section{Latent Islamic Financial Literacy X3}

X3.1 Manifestation of Characteristics of Products and Services. Manifestation of knowledge of the characteristics of Islamic financial products and services which includes a statement of a) product and service features, b) benefits of products and services, c) product and service risks, d) how to obtain products and services, e) consumer rights; X3.2 Manifestation of Community numeracy ability Manifestation of public numeracy skills related to Islamic financial products and services includes statements of a) simple arithmetic, b) calculation of currency value or inflation, c) calculation of profit sharing (loan/savings), d) calculation of the investment return/ risk; X3.3 Manifestation of Attitudes and Behaviors of Society. Manifestation of attitudes and behavior of Indonesian society towards Islamic finance consists of the following statements 1) public financial attitudes related to sharia financial goals consisting of meeting daily needs, survival, and children's education costs; 2) Public financial behavior in achieving sharia financial goals, consisting of saving, compiling financial plans, and working/ looking for work; X3.4 - Delivery Channel Manifest by Sector. Manifestation of Means used (delivery channel) per sharia financial services actor, a) Banking, namely phone banking, ATMs, and bank offices; b) Insurance, namely Bancassurance, Insurance Agent, 
Insurance Office; c) Financing institutions, namely agents, ATMs, offices of financial institutions; d). Pension funds, namely : agents, ATMs, pension fund offices; e) pawnshops, namely agents, ATMs, pawnshops; f) capital market, namely online transactions, agents, capital market offices; X3.5 Manifestation of Information Source Manifestation of sources of information that affect Islamic financial decisions, a) TV commercials, b) Advice from friends (not financial industry players), c) TV and Radio programs, d) Information from the branch offices of financial and service institutions, e) newspaper advertisements, f) Social media; X3.6 - Manifestation of the party invited for a consultation. Manifestation of party consulted for Islamic financial advice, a) Spouse, b) Family/friends, c) Parents, d) Financial Services Institutions officers or other financial practitioners, e) Co-workers.

\section{Result and Discussion}

Results CFA (Confirmatory Factors Analysis)

The measurement model or outer model of the reflective indicator is evaluated using loading stimulation to determine the parameter value of the measurement model, also known as the external model, which is seen in the component matrix table processing results using the SPSS version 20 for the CFA menu. The results related to the external loading model of the exogenous variables of Islamic financial literacy and religiosity are presented in table 1 as follows.

Table 1. Outer Loading Reflective Manifest for Exogenous Sharia

Financial Literacy and Religiosity and Significance of Outer Loading Testing

\section{Outer Loading Outer Loading Value, Loading Criteria Value}

\begin{tabular}{cccccc}
\hline $\begin{array}{c}\text { Religiosity Mani- } \\
\text { fest, } \text { x }^{2}\end{array}$ & & & & & \\
\hline LRT, W5 & 0.995 & $<0.4$ & $>0.4-<0.7$ & $>0.7$ & valid \\
\hline LRR, W6 & 0.725 & $<0.4$ & $>0.4-<0.7$ & $>0.7$ & valid \\
\hline LRI, W7 & 0.702 & $<0.4$ & $>0.4-<0.7$ & $>0.7$ & valid \\
\hline LRK, W8 & 0.694 & $<0.4$ & $>0.4-<0.7$ & $>0.7$ & re-run \\
\hline $\begin{array}{c}\text { Shariah Financial } \\
\text { Literacy Manifest, } \\
\text { x }\end{array}$ & & & & & \\
\hline LRP, W9 & 0.678 & & & & \\
\hline & & & & &
\end{tabular}




\begin{tabular}{|c|c|c|c|c|c|}
\hline Outer Loading & Outer Loading Value, & \multicolumn{4}{|c|}{ Loading Criteria Value } \\
\hline LLKPL,W10 & 0.918 & $<0.4$ & $>0.4-<0.7$ & $>0.7$ & valid \\
\hline LLKMB,W11 & 0.930 & $<0.4$ & $>0.4-<0.7$ & $>0.7$ & valid \\
\hline LLKSR,W12 & 0.659 & $<0.4$ & $>0.4-<0.7$ & $>0.7$ & re-run \\
\hline Outer Loading & Outer Loading Value, & \multicolumn{4}{|c|}{ Loading Criteria Value } \\
\hline LLKDC,W13 & 0.977 & $<0.4$ & $>0.4-<0.7$ & $>0.7$ & valid \\
\hline LLKSI,W14 & 0.432 & $<0.4$ & $>0.4-<0.7$ & $>0.7$ & re-run \\
\hline LLKS,W15 & 0.730 & $<0.4$ & $>0.4-<0.7$ & $>0.7$ & valid \\
\hline
\end{tabular}

Source : Proprietary data (2020).

Based on Table 1, it can be identified that the loading factor value of all reflective manifestations is greater than 0.4 , but there are still those that are less than 0.7. This shows that there are three manifestations of LRT, LRR, LRI, which form the relevant latent religiosity variable, while the LRK and LRP manifestations with values of 0.694 and 0.678 are in the interval between greater than 0.4 but smaller than 0.7 first. After checking for its composite reliability after eliminating the manifest from the outer model, it turned out that the results of the CR values before and after eliminating the LRK and LRP manifestations showed an increase, so it was decided that LRK and LRP were eliminated from the model.

Table 2. Model Accuracy Criteria of Latent Variable

\begin{tabular}{ccccccc}
\hline \multirow{2}{*}{ No. } & Latent Variable & AVE & $\begin{array}{c}\text { Discriminant } \\
\text { Validity }\end{array}$ & & \multicolumn{3}{c}{ CR } \\
\cline { 3 - 7 } & & 0.6209 & 0.788 & 0.743 & 0.8536 & 0.8568 \\
\hline 1 & Religiosity & 0.7383 & 0.8592 & 0.743 & 0.9059 & 0.9177 \\
\hline 2. & $\begin{array}{l}\text { Sharia Financial } \\
\text { Literacy }\end{array}$ & &
\end{tabular}

Source : Proprietary data (2020).

Based on Table 2, the composite rel i ability value can be identified and it shows an increase between before and after the elimination of indicators of which loading values are between 0.4 and 0.7 . Thus, 2 indicators of religiosity and 2 indicators of financial literacy are eliminated from the model. AVE for the latent variable religiosity is 0.6209 , which is greater than 0.5 as the minimum criterion value limit and the latent variable Islamic financial literacy 
is 0.7383 , which is greater than 0.5 as the minimum criterion value limit. Thus the validity and convergent measures of the two latent variables are in the model are already considered well fulfilled.

Evaluation of the factor loading component in the Measurement model (Outer Model) is carried out using the reliability indicator criteria, which shows how many variances of indicators can be explained by latent variables. A reflective indicator must be eliminated (removed) from the model if the loading factor value is less $(<0.4)$. However, the factor loading value is between or equal to 0.4 and less than 0.7 , then an analysis of the second and the third criteria is necessary, namely paying attention to two composite reliability values (Composite Reliability, CR) to detect Convergent Validity (Hair, 2017: 114). If the results of the calculation of the criteria value after eliminating the same factor loading is 0.4 but less than 0.7 compared to without or before eliminating the factor loading, which is between 0.4 and less than 0.7 , it turns out that the results are Smaller, the component loading factor of the manifest needs to be maintained in the outer model, and Greater, then the factor loading component of the manifest needs to be eliminated (removed) from the outer model.

The LRT, LRR, LRI ma $\mathrm{n}$ ifestations are the relevant latent variables for religiosity, while the LRK and LRP manifestations with values of 0.694 and 0.678 , which were in the interval between 0.4 and 0.7 , needed an analysis of their composite reliability first after the manifestations were eliminated from the model outer. It turned out that the results of the calculation of the composite reliability value after and before eliminating the latent manifest of LRK and LRP religiosity showed an increase, so it was decided that the two manifestations of the reflective measurement mentioned above were still eliminated or excluded from the measurement model.

Meanwhile, the LLKPL, LLKMB, LLKD, LLKS manifestations are relevant latent variables for Islamic financial literacy, while the LLKSR and LLKSI manifestations with values of 0.659 and 0.432 were in the interval between 0.4 and 0.7 , the manifest was eliminated from the outer model. It turned out that the results of the calculation of the composite reliability value after and before eliminating the manifest 
revenue manifest in the latent manifestations of Islamic financial literacy LLKSR and LLKSI showed an increase, so it was decided that the two manifestations of the reflective measurement mentioned above were still eliminated or excluded from the measurement model.

Furthermore, by using the Composite Reliability (CR) formula known as the omega coefficient developed by Mc. Donald (Zimbarg, 2005), this coefficient emphasized how far the measuring indicator reflects the compiled latent factors. The greater the indicator that reflects the latent factor, the greater the reliability of the measurement. Coefficient reliability measures consistency (Internal Consistency) and if the value is $>0.6$, it is said to have high consistency. To get the value of construct reliability, it can be calculated through the composite reliability (CR) formula as follows

$$
C R=\rho_{i i}=\frac{\left(\sum \lambda_{I}\right)^{2}}{\left(\sum \lambda_{I}\right)^{2}+\sum \operatorname{var}\left(\varepsilon_{j k}\right)}
$$

Where $\lambda_{i}$ : Loading factor $-\mathrm{i}$ and $\operatorname{var}\left(\varepsilon_{j k}\right)=\left(1-\lambda_{I}^{2}\right)$

Then proceed with the calculation of the assessment criteria for the reflective measurement model to detect the following values: Convergent Validity,

In general, it is detected through the mean value of variance extract (AVE), as follows

$$
A V E=\frac{\sum \lambda_{T}^{2}}{M}
$$

A minimum AVE value of 0.5 to indicate a measure of convergent validity or the average (mean) variant of the extract with a value greater than $(\geq) 0.5$ is used as a determinant of convergent validity. Thus if it is smaller $(<) 0.5$,then it is not valid convergent.

Discriminant Validity

Discriminant Validity (DV) is obtained from the square root of the AVE value, which is mathematically stated:

$$
D V=\sqrt{ } A V E
$$

DV must be greater than the value of the correlation coefficient 
between latent variables. Criteria are based on evaluation of measurements of Hair Jr.'s reflective model. For the value of the loading criteria, there are three categories, namely outer loading values less than 0.4 are deleted or invalid, outer loading values greater than 0.4 and less than 0.7 need to be tested for composite reliability (CR) before and after elimination. If the result is smaller before elimination and greater after elimination, then the manifest is removed from the model.

The results of the modification of the model through the process of re-calculating the loading value after eliminating the three manifestations of the outer reflective model are presented as follows:

Thus, the following Thickness 3 has been adjusted to the rerun of the evaluated manifest:

Table 3. Outer Loading Reflective Manifest for Exogenous Variables

\begin{tabular}{cccc}
\hline Outer Loading & Value of Outer Loading, & Loading Criteria Value \\
\hline Manifest of Religiosity, X2 & & & \\
\hline LRT, W5 & 0.876 & $>0.7$ & valid \\
LRR, W6 & 0.782 & $>0.7$ & valid \\
LRI, W7 & 0.752 & $>0.7$ & valid \\
\hline Manifest of Sharia Financial & & & \\
Literacy, x & & & \\
\hline LLKPLW10 & 0.813 & $>0.7$ & valid \\
LLKMBW11 & 0.733 & $>0.7$ & valid \\
LLKDCW13 & 0.984 & $>0.7$ & valid \\
LLKSW15 & 0.877 & $>0.7$ & valid \\
\hline
\end{tabular}

Source : proprietary data (2020).

From Table 3, it can be seen that the loading values of all manifest both for latent religiosity and latent Islami c financial literacy were all valid with a value greater than 0.7. Furthermore, all the evaluation results of the measurement model (outer model) were restated after eliminating the four manifests presented in the following table.

The results of testing the accuracy of the latent reflective measurement model for identifying the square root value of latent 
religiosity AVE with a value of 0.788 is greater than the correlation value between latent religiosity and the value of syari'ah financial literacy of 0.8592 is greater than the correlation value between the latent syari'ah financial literacy of 0.743 .

Thus, the measurement of the discriminant validity of the two latent variables in the model has been fulfilled properly. Meanwhile, the Composite Reliability (CR) value can be identified in the two latent variables which were greater than 0.7 as the cut-off value. This shows that the accumulated predetermined indicators are able to measure latent variables well or it can be said that both demographics and religiosity latency at the measurement model level was reliable and it can be concluded that the internal consistency of the two reflective exogenous latents was reliable. The manifest variable as the accumulation of indicators in a formative block must be tested for its significance and multicollinearity.

Estimation of external model parameters or measurement (outer model) formative indicators of exogenous demographic variables is called the outer weight value, which is a linear regression coefficient that describes the causal relationship between manifest and endogenous latent of Islamic Financial Literacy, which can be seen in Table 4. The results are as follows:

Table 4. The value of the outer weight of Exogenous Latent Demographics

\begin{tabular}{|c|c|c|c|c|c|c|c|}
\hline \multirow[b]{2}{*}{ No. } & \multirow[b]{2}{*}{$\begin{array}{l}\text { Manifest } \\
\text { Variable }\end{array}$} & \multirow{2}{*}{$\begin{array}{l}\text { Outer } \\
\text { Weight } \\
\text { Value, }\end{array}$} & \multicolumn{2}{|c|}{ t-Student } & \multirow{2}{*}{$\begin{array}{l}\text { Value } \\
\text { VIF }\end{array}$} & \multicolumn{2}{|c|}{ CR } \\
\hline & & & Count & Table & & Before & After \\
\hline 1 & LDG,W1 & 0.738 & 8.7656 & 1.6487 & 1.008 & & \\
\hline 2. & LDU,W2 & 0.837 & 8.4579 & 1.6487 & 1.008 & 0.886 & 0.8975 \\
\hline 3. & LDSP,W3 & 0.799 & 9.6103 & 1.6487 & 1.000 & & \\
\hline
\end{tabular}

Source : Proprietary data (2020).

Based on Table 4, it can be identified that the t-count value of the three manifestations are all greater than $t$ table so that they are declared significant and are still used in the model. On the other hand, all VIF values of the three manifestations are less than 5, so it can be concluded that there is no multicollinearity problem (Joseph 
Hair,2017).

With the modification of the model due to the elimination of invalid and insignificant manifestations, both reflective and formative measurements, this has an impact on reducing the problem of the hypothesis above from four demographic latent hypotheses to three, five latent hypotheses of religiosity to three, and from six endogenous hypotheses of Islamic financial literacy to four hypotheses.

Tabel 1, 2 and 3 show that there was a gap of this research from the previous relevant study in the dimension of religiosity and novelty of study in the dimension of sharia financial literacy having through calculation which shows in the Table 1 found 2 (two) dimension in the religiosity variable, namely experience and moral, as well 2 (two) dimensions in the sharia financial literacy, namely attitude \& behavior (related to religiosity) and information sources (related to demographic) that need to recalculate. Table 2 shows that the result of recalculation found that those dimensions were not valid. Table 3 shows the result after recalculation that valid dimensions were tawhid, ritual, intellectual of religiosity variable and product \& service characteristic, calculation ability, delivery channel, and party that asked for consultation of sharia financial literacy. Meanwhile, Table 4 shows a gap of research in the dimension of income level of demographics.

\section{Evaluation of the structural model or inner model}

The parameter estimation of exogenous latent variables from the structural model (Inner Model) is the value of the weight relation, which can be expressed as the coefficient of the structural model or pathway, and the estimated value of the individual path coefficient in the structural model is interpreted as the standard beta coefficient of OLS (ordinary least) regression. The linear regression model is a causal relationship between exogenous demography and endogenous religiosity in the substructure model-1. In the substructure model-2, there were two exogenous variables demography and religiosity with endogenous Islamic financial literacy, which can be seen in the beta coefficient column in the Coefficients Table, the results in Table 5 as follows. 
Table 5. Value of Inner Model or Structural Model Path Coefficient

\begin{tabular}{ccccc}
\hline \multirow{2}{*}{ VariableS } & \multicolumn{3}{c}{ Structural Model Path Coefficient (Inner Model) } \\
\cline { 2 - 5 } & \multicolumn{2}{c}{$\begin{array}{c}\text { First Substructure } \\
\left(\text { Endogen } \mathrm{X}_{2}\right)\end{array}$} & $\begin{array}{c}\text { Second Substructure } \\
\text { (Endogen }\end{array}$ & \begin{tabular}{c} 
Sharia Financial Literacy $\mathbf{X}_{3}$ ) \\
\cline { 2 - 5 }
\end{tabular} \\
\cline { 2 - 5 } Koefisien & nilai & Koefisien & nilai \\
\hline Demographic $\left(\mathrm{X}_{1}\right)$ & $\mathrm{P}_{21}$ & 0.53 & $\mathrm{P}_{31}$ & 0.470 \\
Religiosity $\left(\mathrm{X}_{2}\right)$ & - & & $\mathrm{P}_{32}$ & 0.745 \\
\hline
\end{tabular}

Source : proprietary data $(2020$

Based on table 5 , the estimated value of the internal model structural equation coefficient parameter for the exogenous demographic variable against endogenous religiosity in the first substructure model was 0.53 , which was equal to the correlation value between the two latents with structural equation 1 .

$$
X 2=0.53 X 1
$$

Whereas, in the second substructure model for exogenous latency demography and religiosity, the estimated value of the structural model parameter coefficient was 0.47 and 0.745 , respectively, which was expressed in the equation 2.

$$
\mathrm{X} 3=0.47 \mathrm{X} 1+0.745 \mathrm{X} 2
$$

The measurement equation in the external model (outer model) is based on the acquisition of the loading factor and outer weight values which are presented in Tables 2 and 5.Thus, the equations in the measurement model (outer model) and structural (inner model) are written respectively. According to the following, a model describes a linear relationship and has causality between manifest variables with latent and latent variables. It can be reflected in the measurement model equations for the successive external model (outer model) for the external model (outer model) on exogenous variables.

DemographyX1=0.738X1.1 $+0.837 X 1.2+0.799 X 1.3$

Religiosity $X 2=0.876 \times 2.1+0.782 \times 2.2+0.752 \times 2.35$

Sharia financial literacy $X 3=0.813 \times 3.1+0.733 \times 3.2+0.984 \times 3.3$ $+0.877 X 3.4$

(8)

Furthermore, ba s ed on the structural equation (inner model) 
successively:

Sub structure-1 $\quad \boldsymbol{X} \mathbf{2}=\mathbf{0 . 5 3 \times 1 ( 9 )}$

Sub structure-2 $\quad \boldsymbol{X} 3=\boldsymbol{0 . 4 7 X 1 + 0 . 7 4 5 X 2}(\mathbf{1 0})$

All coefficients of both measurement and structural models can be depicted in the structural and measurement diagrams in Figure 2. Path diagram of the Measurement Model and Structural Manifest and Latent Variables are shown on the following pages.

Indicators of demographic variables have a reflective measurement coefficient which shows the effect of indicators on demographic variables as follows.

\section{$(X 1=0.952 \times 1.1+0.839 \times 1.2+0.830 \times 1.3+0.609 \times 1.4)$}

In the indicator of the religiosity variable, there is a reflective measurement coefficient which shows the effect of the indicator on the religiosity variable, which is as follows.

\section{$(X 2=0.995 \times 2.1+0.725 \times 2.2+0.702 \times 2.3+0.694 X 2.4+$ $0.678 \times 2.5)$}

Indicators of Islamic financial literacy variables have a formative measurement coefficient that shows the influence of the Islamic financial literacy variable on the indicator of the Islamic financial literacy variable on the problem as follows.

$(X 3=0.918 \times 3.1+0.930 \times 3.2+0.659 \times 3.3+0.977 \times 3.4+0.432 \times 3.5$ $+0.730 \times 3.6)$

On the other hand, there is a structural coefficient of direct influence of demographic variables on Islamic financial literacy and a structural coefficient of indirect influence of demographic variables through religiosity on Islamic financial literacy. The religiosity variable has a structural coefficient of direct influence on Islamic financial literacy. The coefficient of the structural measurement results of the demographic variable on religiosity is

$$
\mathrm{X} 2=0.53 \mathrm{X} 1
$$

and the structural coefficient for the demographic variable and the variable of religiosity on Islamic financial literacy is 


\section{$X 3=0.47 X 1+0.745 X 2$}

The following is a path diagram for the modified model after eliminating the three manifestations of the reflective measurement model and one manifest variable from the formative measurement model.

Based on the results of calculations regarding the evaluation criteria for the modified structural model through processing using a combination of SPSS version 20 and $\mathrm{R}$ version 3.6.2 as a whole for the sub-structure equation-1, the results are presented in Table 6 as follows:

\begin{tabular}{ccccc}
\multicolumn{2}{c}{ Table 6 Evaluation } & Criteria for Structural Model 1 (Inner Model) \\
\hline \multirow{2}{*}{ No. } & $\begin{array}{c}\text { Evaluation Criteria for } \\
\text { Structural Model }\end{array}$ & \multicolumn{2}{c}{ Value of Component } & Decision \\
\cline { 3 - 4 } & & Value & Criteria & Substancial \\
\hline 1 & & 0.555 & $0.3-0.67$ & Large \\
2. & Efect () & 0.616 & $>0.35$ & Own prediction of relevancy \\
3. & $\mathrm{Q}^{2}$ & 0.308 & $>0$ & Model Fit \\
4. & GoF & 0.328 & $>0.25$ & \\
\hline
\end{tabular}

Source : proprietary data (2020).

Based on Table 6. it can be identified from the four evaluation criteria of the structural model or Inner Model, the R2 value is 0.555 . which means that the variability or diversity of endogenous variables of Islamic financial literacy can be explained by the exogenous latent variables demographics and religiosity of $55.5 \%$, while the remaining 44.5. \% explained by other factors.

For the effect size ( $f \wedge 2$ ) with a value of 0.616 , it can be interpreted that the exogenous latency of demography and religiosity is able to reflect a model with a large influence. For a Q2 value of 0.308 , it shows that the exogenous latent variables of demography and religiosity are able to predict the Islamic financial literacy model well. The GoF value of 0.328 is between 0.25 and 0.36 so that it is interpreted that the exogenous variables demography and religiosity have a performance from moderate to large in validating the model. Thus, this indicates that the structural model has the validation of the predictive ability of the PLS model as a whole, both for measurement and structural models, which is acceptable 
because it is a Fit model.

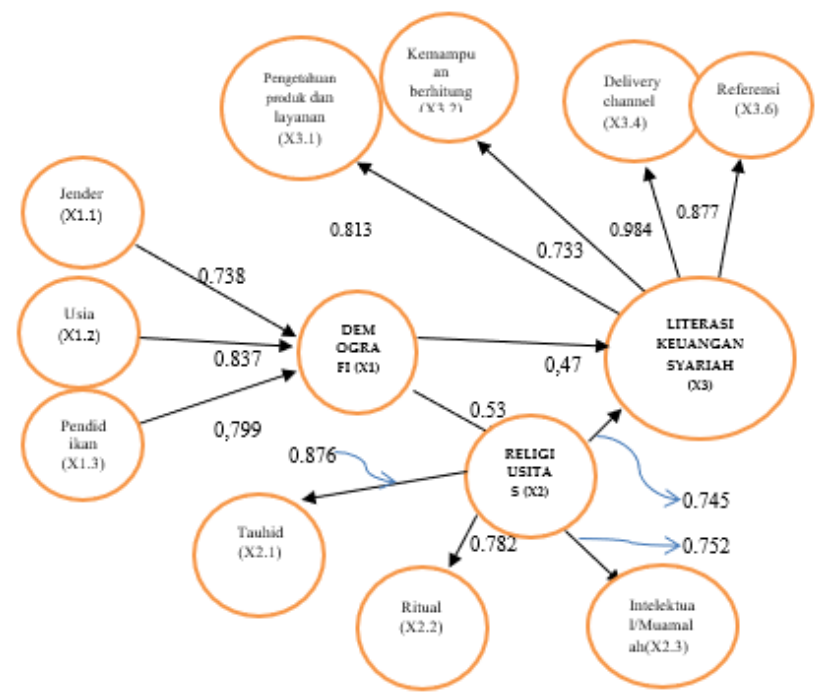

Figure 2. Measurement and Structural Model Path Diagram Manifest and Latent Variables

Source : Proprietary data (2020).

\section{Hypothesis Tests}

The results of calculations for determining the structural model coefficients, either one or two, using SPSS version 20 software have been obtained in Chapter IV and presented in Table 5, and the results of hypothesis testing using the resampling-based bootstrap method with data processing using $\mathrm{R}$ software are presented in Table 7 as follows.

Table 7. Hypothesis Testing for the Structure Model (Inner Model)

\begin{tabular}{|c|c|c|c|c|c|}
\hline \multirow{2}{*}{ Latent Variable } & \multicolumn{2}{|c|}{ Endogenous Variable Path Coefficient } & \multirow{2}{*}{$\mathrm{t}$-Count } & \multirow{2}{*}{$\mathrm{t}$-Table } & \multirow{2}{*}{ Criteria } \\
\hline & Religiosity & Sharia Financial Literacy & & & \\
\hline Demographics & 0.53 & - & 96.224 & 1.64869 & Significant \\
\hline Demographics & - & 0.47 & 17.33 & 1.64869 & Significant \\
\hline Religiosity & - & 0.745 & 21.54 & 1.64869 & Significant \\
\hline
\end{tabular}

Source : Proprietary data (2020).

Based on Table 7 above for the inner model in sub-structure-1, it can be identified that the t-count value is 449.94, while the t-table 
value is 1.64869 for the 0.05 significance level and the 397 degrees of freedom (n-k-1) is 1.6467. Thus it can be concluded that Ho is rejected and $\mathrm{H} 1$ is accepted. The results of hypothesis testing for the sub-structural model-2, for the exogenous demographic latent structure coefficient, show that the t-count is 17.33 , while the t-table value is 1.64869 for the 0.05 significance level and 397 (n-k1) degrees of freedom of 1.6467 . Thus it can be concluded that Ho is rejected and hypothesis H1 is accepted. The test results for the exogenous latent structure religiosity coefficient is 21.54 while the $\mathrm{t}$-table value is 1.64869 . The $\mathrm{t}$-count value is greater than the $\mathrm{t}$-table value for the 0.05 significance level and the 397 (n-k-1) degrees of freedom of 1.6467 , so it is concluded that $\mathrm{Ho}$ is rejected and the hypothesis $\mathrm{H} 1$ is accepted.

\section{Conclusion}

Based on the results of the analysis and discussion above, it can be concluded that there is a significant effect of demographic exogenous latency on endogenous latent religiosity, there is a significant effect of demographic exogenous latency has a significant effect on endogenous latency of Islamic financial literacy and there is a significant effect of religiosity on Islamic financial literacy. The dimension of the income level of demographic variable and dimension of experience and moral of religiosity variable are gap of this study from the relevant previous study.

The novelty of this study is that dimensions that do not support the significant effect of demographic and religiosity variables on Islamic financial literacy are the level of income, morals and experience if they are associated with moral hazard because they are supported by manifestations related to morality. The dimension of attitude \& behavior (related to religiosity variable) and information sources (related to demographics variable) of sharia financial literacy are not valid. For further research, it is necessary to pay attention to demographic factors, indicators of income strata, religiosity, indicators of morals and experience, as well as Islamic financial literacy, attitude and behavior indicators, and references. It also is better to use a larger sample size so that more accurate results are obtained. 


\section{References}

Amaral, Ernesto F. L. (2019). An Introduction to Demography, http:// www.ernestoamaral.com/docs/soci312-19spring/Lecture01. pdf.

Bawono, Anton. (2014). Kontribusi Religiositas Dalam Rasionalitas Konsumsi Rumah Tangga Muslim, INFERENSI, Jurnal Penelitian Sosial Keagamaan 8(2), 287.

Ermawati, Nanik. tt. Pengaruh Religiusitas, Kesadaran Wajib Pajak dan Pengetahuan Perpajakan Terhadap Kepatuhan Wajib Pajak. Jurnal STIE Semarang, 10(1), 106-122

Hair, Joseph F. Jr. et.al. (2017). A Primer Partial Least Squares Structural Equation Modelling (PLS-SEM), California: SAGE Publications Ltd.

Johan, Zaimy Johana and Putit, Lennora. (2016). Conceptualizing the Influences of Knowledge and Religiosity on Islamic Credit Card Compliance. Procedia Economics and Finance, 37, 480 $-487$

M., Mustapha, \& S., Jeyaram. (2015). Financial Literacy and DemoGraphic Factors. Journal of Technology Management and Business, 2(1). https://publisher.uthm.edu.my/ojs/index.php/ $\mathrm{jtmb} / \mathrm{article} / \mathrm{view} / 1091$

Meimouneh, Saeed Karimi et al. (2014). A Survey to The Influence of Demographic Characteristics on The Level of Financial Literacy of Irlandian Students. Interdisciplinary Journal of Contemporary Research in Business. 5(11).

Muthohar, AM. (2019). Analysis of Influence of Intrinsic Aspect, Demography Aspect and Service of Zakat Institution toward Zakat Payment to Zakat Institution. INFERENSI, Jurnal Penelitian Sosial Keagamaan, 13(1), 25-50.

Otoritas Jasa Keuangan. (2019). Survey OJK 2019: Indeks Literasi dan Inklusi Keuangan Meningkat, https://www.ojk.go.id/id/ berita-dan-kegiatan/siaran-pers/Pages/ 
PEW Research Center. tt. The Global God Divide. https://www. pewresearch.org/global/2020/07/20/the-global-god-divide/

World".

(2018). "The Age Gap in Religion Around the

Rehman, Ateeq-ur and Shabbir, Muhammad Shahbaz. (2010). "The Relationship between Religiosity and New Product Adoption", Journal of Islamic Marketing, 1(1), 63-69.

Sarwono, Jonathan. (2015). Mengenal PLS-SEM. diakses pada 17 Maret 2020 dari https://www.jonathansarwono.info/teori_ spss/PLSSEM.pdf

Shusha, Amir Ali. (2017). Does Financial Literacy Moderate the Relationship among Demographic Characteristics and Financial Risk Tolerance? Evidence from Egypt. Australian Accounting, Business and Finance Journal, 11(3), 67-86.

Soma, AM. et.al. (2017). Religiosity and Islamic Banking Product Decision: Survey on Employees of PT. Telekomunikasi Indonesia, Etikonomi 16(1), 25-42.

Syaparuddin. (2014). Model Pengembangan SDM Industri Perbankan Syariah pada Islamic Banking School, INFERENSI, Jurnal Penelitian Sosial Keagamaan, 8(2), 351-372.

. (2019). Measuring the Welfare Level of Local Community Who Take Sustainable Business Financing Based on Local Wisdom In the Islamic Microfinance Institution, INFERENSI, Jurnal Penelitian Sosial Keagamaan, 13(1), 1-24.

Universitas Pajajaran. (2018). Buku Ekonomi Kependudukan. http://www.feb.unpad.ac.id/dokumen/files/BUKUKEPENDUDUKAN.pdf

Wardayati, SM, et.al. (2014). Pengembangan Model Reduksi Resiko dan Eksalasi Kinerja Pembiayaan Mudharabah pada Lembaga Keuangan Mikro Syariah, INFERENSI, Jurnal Penelitian Sosial Keagamaan, 8(2), 331 
Djubaedi Yunus, Ahmad Rodoni, Amilin, Riris Aishah Prasetyowati

Wunsch, Guillaume. (2007). Confounding and Control. Demographic Research, 16, 97-120. 